\title{
SYSTEM OF DERIVATIONAL CHAINS IN RUSSIAN NOUNS: LINGUISTIC AND METHODICAL ASPECTS
}

\author{
Natalya S. Subbotina ${ }^{1}$ \\ Venera G. Fatkhutdinova ${ }^{2}$ \\ Elena I. Koriakowcewa ${ }^{3}$
}

\begin{abstract}
The article describes the phenomenon of consistent derivation of words. The concept "word-forming chain" is used for its description in Russian linguistics. The subject of the study is the word-forming chains of nouns as a methodologically relevant means of language teaching. The purpose of the work is to characterize the structural and semantic properties of word-forming chains in the sphere of Russian nouns and to reveal the ways of their systematization. The presentation and the description of derivative groups forming word-building chains is carried out using the system-structural and functional-semantic methods. The study found that the typology of the substantive word-building chains of the Russian language is based on their
\end{abstract}

system-structural reproducibility. The system is formed by binary and polynomial, linear and annular, complete and incomplete chains, as well as the chains that include monomotivated and poly-motivated derivatives. It is proved that the word-forming chain is one of the ways to cognize the systemic organization of the language wordforming level, the morphemic structure of derived words, the idiomatic nature of their semantics, and the linguocultural specifics of linguistic nomination.The purposeful methodical work on the study of consistent derivation as a language phenomenon promotes an active perception of many lexical and grammatical phenomena, as well as the development of the necessary skills of

\footnotetext{
${ }^{1}$ Kazan Federal University. University of Natural Sciences and Humanities in Siedlce. favenera@mail.ru.

${ }^{2}$ Kazan Federal University. University of Natural Sciences and Humanities in Siedlce. favenera@mail.ru.

${ }^{3}$ Kazan Federal University. University of Natural Sciences and Humanities in Siedlce. favenera@mail.ru.
} 
ISSN | 2179-7137 | http://periodicos.ufpb.br/ojs2/index.php/ged/index

Russian derivative use in speech practice.

Keywords: Russian language, methodology, word formation, noun, word-formation chain, derivational relations.

\section{Introduction}

The modern method of teaching Russian as a foreign language considers word-formation analysis as an auxiliary linguodidactic technique. It is used to describe the morphemic structure of a word (inflectional and word-forming affixes) during the study of morphological categories and the ways of grammatical semantics expression. Meanwhile, the word-forming structure and the significance of Russian derivative words, the heterogeneous nature of the semantic increments makes quite reasonable difficulties for foreign students. They are caused by the interfering influence of their native language, since, as is known, the system of derivational and morphological means of typologically distant languages has a pronounced specificity, see [Corbett
2010], [Tekin 2012], [Lieber, Stekauer 2014], [Word-Formation 2015].

Any derivative words in a man's mind relate primarily to the root morpheme semantics. In this regard, in order to enrich and activate the vocabulary of students, the presentation of a derived word in the environment of other single root words constituting word-building nests, chains and paradigms will be methodologically optimal.

With this approach, the use of both word-formative and explanatory dictionaries that fix the semantic structure of motivated and motivating words [Nurullina, Yusupova 2016: 92], which shortens the path from the semantization of a word to its inclusion in the active speech-cognitive process, becomes important in the learning process.

In the process of Russian language teaching, a special attention should be paid to the phenomenon of the consistent production of words, which implies the derivability of each subsequent word from the preceding one. The term "word-building chain" is used to describe this phenomenon in linguistics. Under the word-formation 
chain in Russian derivatology is "a number of single-root words connected with each other by the relations of sequential derivation" [Tikhonov 2015: 41]: вода $\rightarrow$ водяной $\rightarrow$ водянистый $\rightarrow$ водянистость; вода $\rightarrow$ водный $\rightarrow$ наводнить $\rightarrow$ наводнение.

The subject of our study was the word-forming chains of nouns as a methodologically relevant means of language teaching.

The purpose of the work is to describe the structural and the semantic properties of word-formation chains in the sphere of Russian nouns and to reveal the ways of their systematization.

\section{Methods and Materials}

The reliability of the obtained results is ensured by the use of various methods, the main one of which is the system-structural method involving the functional-semantic analysis that helps to determine the features of wordformation determination for certain concepts. The presentation of derivative groups forming word-building chains is carried out using a wide range of didactic-methodical methods, such as systematization, generalization and opposition, as well as prospective wordbuilding analysis. The material for the study was the "Word-forming dictionary of Russian language" [Tikhonov 1985] and other lexicographic sources.

\section{Results and Discussion}

One aspect of sequential production phenomenon study in the Russian language system is the study of word-building chains within a certain part of speech. In our case, the specifics of the structural-semantic organization of the units under study are determined by the derivational potential of noun. Thus, other nouns, verbs, adjectives and adverbs are derived from the nouns in Russian language. Both universal and specific derivational meanings are implemented with intrasubstantial wordformation within the word-forming chain. They are expressed in the corresponding word-formation types and models characteristic of many natural languages.

What is the specificity of the structural and the semantic organization of a word-forming chain as a collection of single-root words? 
ISSN | 2179-7137 | http://periodicos.ufpb.br/ojs2/index.php/ged/index

A word-forming chain, as well as other complex units, combining single-root words, consist of wordbuilding pairs. So, the single wordformation chain from a source link to a final one is made up by the following word-building pairs: земля $\rightarrow$ приземлить, приземлить $\rightarrow$ приземлиться, приземлиться $\rightarrow$ приземление.

An important factor of consistent derivation is the definition of its boundaries, since it can not be infinite. The boundaries of the chain indicate the qualitative and functional differences between its links. The most opposed are the initial and the final links: the original is the non-derivative, the producing, and the final is the derivative, the non-derivative: гость $\rightarrow$ гостить $\rightarrow$ угостить $\rightarrow$ угощать $\rightarrow$ угощаться.

The links in the middle of the chain have the function of a generating word and the quality of a final (derived) link. If an original word can be included into several chains at once, then the final one - into one only: соль $\rightarrow$ солить $\rightarrow$ засолить $\rightarrow$ засаливать $\rightarrow$ засаливаться; соль $\rightarrow$ солить $\rightarrow$ рассол $\rightarrow$ рассольник $\rightarrow$ рассольничек.
205

Many scholars call the successive formal complication of its members as the most important indicator of the word-formation chain structure. The process of joining the formant of the previous stage into the base of the next stage is carried out at the expense of language morphemic and morphological arsenal, which is very developed in Russian language. As a rule, the last word of the chain is a multi-morphic derivative: тень $\rightarrow$ тенить $\rightarrow$ оттенить $\rightarrow$ оттенок $\rightarrow$ разнооттеночный $\rightarrow$ разн-от-тен-оч-н-ость. In fact, the formants are increased and the ability of a derivative to be a generating word is decreased from a link to a link: век $\rightarrow$ вечный $\rightarrow$ вечнозеленый. Other words are not formed in Russian language from the adjective вечнозелёный.

As you know, reproducibility and repeatability are the main typological properties of word formation complex units. In this regard, let us examine in detail the typology of substantive word-building chains in Russian language.

From a formal point of view, the word-forming chains can be characterized by several features, read in detail [Shirshov 1999]. By the number of 
components, the chains can be binary and polynomial. Binary ones consist of two words - the source and the derivative: антресоль антресольный, анчоус $\rightarrow$ анчоусный, джаз $\rightarrow$ джазовый, диабет $\rightarrow$ диабетический, диаметр $\rightarrow$ диаметральный.

Polynomial consist of three or more components: место $\rightarrow$ вместить $\rightarrow$ вместимость $\rightarrow$ пассажировместимость; груз $\rightarrow$ грузить $\rightarrow$ погрузить $\rightarrow$ погрузка $\rightarrow$ углепогрузка $\rightarrow$ углепогрузочный. They can include up to seven links, for example: мир (1) $\rightarrow$ мирить (2) $\rightarrow$ примирить (3) $\rightarrow$ примирение (4) $\rightarrow$ примиренец (5) $\rightarrow$ примиренческий (6) $\rightarrow$ примиренчески (7).

According to the lexicalgrammatical relation of an initial word and a final link, the chains are divided into linear and annular ones. In linear chains, the initial and the final links belong to different parts of speech: век (noun) $\rightarrow$ вечный $\rightarrow$ долговечный $\rightarrow$ долговечно $\rightarrow$ недолговечно (adverb); век (noun) $\rightarrow$ вековать $\rightarrow$ отвековать (verb); век (noun) $\rightarrow$ пол/век(a) $\rightarrow$ полувековой (adjective).
In ring chains, the original and the final links belong to one part of speech, in our case to the noun: весть $\rightarrow$ предвестить $\rightarrow$ предвестник $\rightarrow$ предвестница; вера $\rightarrow$ верить $\rightarrow$ уверить $\rightarrow$ уверенный $\rightarrow$ неуверенный $\rightarrow$ неуверенность; вера $\rightarrow$ верить $\rightarrow$ уверить $\rightarrow$ разуверить $\rightarrow$ разуверение. In the formations listed, the final link of the chain is an abstract noun. In Russian, nomina abstracta "is a microsystem, a nucleus the center of which is the word-formative category of verbal action names. Word-forming categories and the types of non-verbal (denominative and adjective-based) action names are at the periphery of this microsystem" [Koryakovtseva 1998: 3].

On the basis of "successive or inter-stage affixing of affixes" the chains are divided into complete and incomplete ones. In complete chains, each level of word formation is marked by its affix: ум $\rightarrow$ разум $\rightarrow$ вразумить $\rightarrow$ вразумительный $\rightarrow$ невразумительный невразумительно. In incomplete chains, the stepwise principle of a nest deployment gives way to an inter-stage one: мода $\rightarrow$ модист/ка (there is no "модист" link), купе $\rightarrow$ 
ISSN | 2179-7137 | http://periodicos.ufpb.br/ojs2/index.php/ged/index

купиров/анный (the missing link is "купировать"), дифтонг $\rightarrow$ дифтонгиз/ация (there is no "дифтонгизировать" link) драже $\rightarrow$ дражирова/ние (there is no "дражировать" link), дождь $\rightarrow$ дождев/ание (there is no "дождевать" link).

On the basis of "one motivation for a finite (or a non-finite) link or more" the chains are divided into two types: 1) including monomotivated derivatives (in binary and incomplete chains, where the relations between links are unambiguous and do not allow any other solutions): крахмал $\rightarrow$ крахмальный; лыжа $\rightarrow$ лыжня; 2) including poly-motivated derivatives (in polynuclear and complete chains): крахмал $\rightarrow$ крахмалить $\rightarrow$ подкрахмалить $\rightarrow$ подкрахмалиться $\rightarrow$ подкрахмаливаться (1); крахмал $\rightarrow$ крахмалить $\rightarrow$ подкрахмалить $\rightarrow$ подкрахмаливать $\rightarrow$ подкрахмаливаться (2); лыжа $\rightarrow$ горнорлыжник (1) $\rightarrow$ горнолыжница $(1) ;$ лыжа $\rightarrow$ горнолыжный $\rightarrow$ горнолыжник (2) $\rightarrow$ горнолыжница (2); атлет $\rightarrow$ атлетический (1); атлет $\rightarrow$ атлетика $\rightarrow$ атлетический (2).

A consistent derivation is certainly the phenomenon not only structural, but also semantic one, as the word-forming chain visually reflects both formal and semantic increments in the word formation act. The analysis of the semantic structure of word-building chains and, in particular, of all types of figurative meanings arising in its links at a certain stage of derivation, gives us an idea of semantics transformation in derived words as the lexemes of a special kind. As a rule, such semantic shifts indicate the appearance of new meanings and the development of a phraseological type of meaning: волос $\rightarrow$ простоволосый 'with an uncovered head', простоволосить - to take off a head cover forcefully, to disgrace' $\rightarrow$ опростоволосить - to take off a head cover forcefully, to disgrace' $\rightarrow$ опростоволоситься - to be in a disadvantageous, unpleasant, ridiculous position; соль $\rightarrow$ хлебосол - 'hospitable person' $\rightarrow$ хлебосольство - 'readiness and ability to treat hospitably, hospitality'.

The analysis of the internal form of this kind of derivatives, especially in a foreign-language audience, must be accompanied by a linguistic and a cultural comment that reveals the socio-cultural norms and the 
value system of Russian language speakers, see, for example, [Rakhimova, Chupryakova, Safonova 2017], [Shchuklina 2017]. Often, this kind of idiomaticity, arising on the basis of one of the meanings of an original word, is transferred from one link to another: венец $\rightarrow$ венчать $\rightarrow$ венчаться $\rightarrow$ обвенчаться 'to marry'; венец $\rightarrow$ венчать $\rightarrow$ увенчать $\rightarrow$ увенчаться $\rightarrow$ увенчиваться 'to come to an end, to end with something successful, pleasant'; венец $\rightarrow$ венчать $\rightarrow$ развенчать $\rightarrow$ развенчивать $\rightarrow$ развенчивание 'to deprive the former glory, the previous general recognition, showing the negative side of someone, something'.

In the word-building chain ветер $\rightarrow$ ветреньй $\rightarrow$ ветреник $\rightarrow$ ветреничать the figurative meaning of the adjective ветреньй 'легкомысленный, пустой' is passed on to the next link - the noun ветреник 'the one who acts stupidly, light-minded'. It should be noted that the names of persons in Russian have an increased "linguistic and cultural potential" [Sadrieva, Erofeeva 2016: 206], see also ветер $\rightarrow$ ветрогон 'the same as ветреник'.
208

The presentation of wordforming chain mechanism during Russian language lesson is an effective and an optimal way of student grammatical competence expansion and activation. Using the example of the word-forming chain, one can demonstrate the derivation of verbs, their specific and collateral correlations, as well as participial forms, from nouns: груз $\rightarrow$ грузить (imperfective) $\rightarrow$ разгрузить (perfective) $\rightarrow$ разгружать (imperfective) $\rightarrow$ разгружаться (return or passive verb) $\rightarrow$ разгружающийся (participle) $\rightarrow$ саморазгружающийся; карман $\rightarrow$ прикарманить (perfective) $\rightarrow$ прикарманивать (imperfective) $\rightarrow$ прикарманиваться (return or passive voice). These verbal forms in Russian take an active part in derivational processes in contrast to the languages of other morphological types, see [Pounder 2011].

\section{Conclusions}

Thus, the main feature of the word-forming chain as one of the complex units of word-formation is the relations of the sequential production of its members. The consistent derivation in Russian language is the phenomenon of 
a special kind, directly related to the morphological structure of the language, the inventory of its derivational means, and the productivity of word-building types and models.

The structural and semantic analysis of the word-formation chains of nouns makes it possible to characterize the word-forming potential of a given part of speech, to reveal the degree of derivational process intensity in different semantic groups, as well as the basic patterns of adjective-based wordformation in general.

The typology of the substantive word-building chains of Russian language is based on their systemstructural reproducibility. The system is formed by binary and polynomial, linear and annular, complete and incomplete chains, as well as the chains that include monomotivated and poly-motivated derivatives. Their methodological relevance in the study of Russian as a foreign language is obvious.

The word-formation chain is one of the ways to cognize the systemic organization of the word-formative level of the language, the structural-semantic complexity of derived words, the idiomatic nature of their semantics, and the linguocultural specifics of linguistic nomination process.

\section{Summary}

The results of the study show that a purposeful methodological work on the study of consistent derivation as a language phenomenon contributes to an active perception of many lexical and grammatical phenomena, as well as the development of the necessary skills to use the Russian derivatives in speech practice. The comprehension of the morphemic structure of a lexical unit derivative must occur simultaneously with the process of its semantification against the background of other related words. Lexical units in this case are remembered not mechanically and not in isolation, but in connection with other single-root words that help to reveal the meaning of a new word. Such memorization presupposes logical reasoning and a language conjecture, based on the epidigmatic relations of words.

The word-building chain allows a teacher to illustrate an exceptional variety of ways for Russian word development, as well as to form an idea of the main parts of speech derivational 
ISSN | 2179-7137 | http://periodicos.ufpb.br/ojs2/index.php/ged/index

potential. This linguistic methodic attitude allows you to optimize the assimilation of Russian derivatives and opens up new opportunities for language mastering.

\section{Acknowledgements}

The research is performed according to the Russian Government Program of Competitive Growth of Kazan Federal University.

\section{References}

Corbett, G.G. Canonical derivational morphology. In: Word structure. V.3. Issue 2, 2010. pp: 141 - 155 .

Tekin, Ö. Grundlagen der Kontrastiven Linguistik in Theorie und Praxis. Tübingen: Stauffenburg Verlag, 2012. pp: 300 .

Lieber R., Stekauer P. (eds.), The Oxford Handbook of Derivational Morphology. Oxford University Press, 2014. pp: 768.

Word-Formation. An International Handbook of the Languages of Europe. Ed. By Muller, Peter O. /Ohnheiser, I. / Olsen, S. / Rainer, F. Verlag: De Gruyter
Mouton, 2015. Volume 1. pp. 802.

http://www.degruyter.com/view/serial/1 $\underline{29039}$

Nurullina G.M. Yusupova Z.F. The use of dictionaries in teaching Russian language to bilingual students // Modern Journal of Language Teaching Methods: Special Issue (December 2016). pp: $92-$ 96.

Tikhonov A.N. Basic concepts of Russian word formation // Tikhonov A.N. The dictionary of Russian language. In two volumes. Volume I. M.: "Russian Language", 1985. pp. 18 - 52.

Tikhonov A.N. Russian language dictionary. In 2 volumes. Moscow: "Russian Language", 1985.

I.A. Shirshov. Theoretical problems of nesting. Moscow: Prometheus, 1999. $236 \mathrm{p}$.

E.I. Koryakovtseva Names of action in Russian language: history, wordformation semantics. M.: RAS, Institute of Russian language named after V.V. Vinogradov, 1998. 220 p. 
Rakhimova D.I., Chupryakova O.A.,

Safonova S.S. Binary opposition «rich poor» in Russian, Tatar and English linguocultures // QUID: Investigacion, ciencia y tecnologia, 2017, Special Issue 1, pp: 2495-2501.

Shchuklina T.Y. Precedent phenomena as the source of non-usual wordformation in the contemporary Russian mass media // Przegląd Wschodnioeuropejski. - 2017. - VIII/1. pp: 209-217.

Sadrieva E.V., Erofeeva I.V. Representation of human's image by using word-formation resources in the language of Russian chronicles (using the example of nouns with suffixes (ьн) икъ) //Journal of Language and Literature. - 2016. - Vol.7, No. 1.pp: 203-206.

Pounder A. Process and Paradigms in Word-Formation Morphology. De Gruyter Mouton, 2011. 744 p 